\title{
Host Plant Resistance, Physio-Morphic Character and Screening of Chickpea Pod Borer Helicoverpa armigera (Hübner)
}

\author{
Qurban Ali ${ }^{1}$, Muhammad Faheem Akhtar ${ }^{1}$, Asad Aslam ${ }^{1 *}$, Muhammad Shehzad ${ }^{2}$, Muhammad Jamal' \\ Humaira Malik ${ }^{1}$, Imran Nadeem ${ }^{1}$, Aqsa Abbas ${ }^{1}$, Muhammad Jawad Saleem ${ }^{1}$, Tamsila Nazir ${ }^{1}$ and Kanwal \\ Hanif $^{1}$
}

${ }^{1}$ Entomological Research Institute, Ayub Agriculture Research Institute, Faisalabad, Pakistan; ${ }^{2}$ Department of Entomology, Pir Mehr Ali Shah Arid Agriculture University Rawalpindi, Pakistan; ${ }^{3}$ Oilseed Research Institute, Ayub Agriculture Research Institute, Faisalabad, Pakistan; ${ }^{4}$ Institute of Home Sciences, University of Agriculture, Faisalabad, Pakistan.

Abstract | Pod borer (Helicoverpa armigera) is economically vital insect pests for chickpeas and caused huge
yield losses in south Asian countries. Host plant resistance, physio-morphic characters counteract the ability
of insect to demage and to cause minimum reduction in yield. The experiment was conducted under natural
and semi-natural conditions to determine the host plant resistance of nine (09) chick pea advance genotypes
viz., (K01211, K01216, K01241, K01242, K09012, KO1308, K014001, K014002, K-14003) and one (1)
control (Noor). Antixenosis was calculated by counting the number of eggs per stem and antibioses was
assessed by counting the number of infested leaves and survival rate of pest. The results revealed that $H$.
armigera infestation started to appear during the second fortnight of February that continued to increase till
the crop maturity. Lowest number of eggs (115) were recorded on K01308 while K09012 and K01242 were
found to be most preferred for oviposition (261 and 250, respectively). Maximum larval survival about 0.98
was recorded on K09012 followed by K01216. Whereas, minimum was recorded on K014001 followed by
K01308 and K014002.Minimum leaf damage percentage (1.1289\%) was observed in K014001 followed by
K014002, K14003 and K01308 however maximum damage (7.25\%) was observed in K01242.
Received | November 13,2020; Accepted | December 28,2021; Published | December 25, 2021
"Correspondence | Asad Aslam, Entomological Research Institute, Ayub Agriculture Research Institute, Faisalabad, Pakistan; Email:
mr.awan2233@gmail.com
Citation | Ali, Q., Akhtar, M.F., Aslam, A., Shehzad, M., Jamal, M., Malik, H., Nadeem, I., Abbas, A., Saleem, M.J., Nazir, T., and Hanif, K.,
2021. Host plant resistance, physio-morphic character and screening of chickpea pod borer Helicoverpa armigera (Hübner). Journal of Innovative
Sciences, 7(2):312-317.
DOI | https://dx.doi.org/10.17582/journal.jis/2021/7.2.312.217
Keywords | Antibiosis, Antixenosis, Host plant resistance, Chickpea, Pod borer, Varietal screening

\section{Introduction}

$\mathrm{C}$ hickpea (Cicer arietinum L.) is most important in Pakistan pulse crop that accounts for 76 percent of country's total pulse production (Anonymous, 2018). In Pakistan, C. arietinum is cultivated in both rainfed and irrigated area of 944 thousand hectares with an annual production of 438 thousand $n$ tons per year (Anonymous, 2019). It is good source of dietary fiber, protein and carbohydrates (Jukanti et al., 2012), and known as king of pulses in the world (Bhatt and Patel, 2001). Being leguminous crop it improves the soil health and leaves behind substantial amount of nitrogen for subsequent crop (ICRISAT, 2005).

The chickpea pod borer Helicoverpa armigera (Lepidoptera: Hübner) is most severe insect pest in Asian countries due to its high mobility, fecundity rate and overlapping generations (Sarode, 1999). On an average, it causes $30-40 \%$ yield loss in chickpea 
crop (Rahman, 1990; Sarwar et al., 2009). H. armigera adult is light reddish-brown moth with a prominent dot at the middle of forewing. Its larvae colour varies from green, brown or yellow (Zahid et al., 2008). It lays eggs mostly on leaves and flowers. The newly emerged larva feeds on leaves portion but later stages of the pest prefers to feed on seeds inside the pod (Sarode, 1999).

Insecticides application is traditional and very effective method to control $H$. armigera (Nimbalkar et al., 2009). However, insect resistance issues have risen and injurious use of Pesticide (Kranthi et al., 2002). Therefore, development of tolerant or resistant varieties to $H$. armigerais dire need of hour for economical and sustainable pest management as cultivated varieties shows very low to moderate levels of pest resistance (Sharma et al., 2005).

Larval damage, survival rate (Suzana et al., 2015) and adult's ovipositional preference (Kulkarni et al., 2004) varies among host plants. Different physiomorphic and biochemical characteristics of hostplant attributes for antibiosis and antixenosis mechanisms of resistance. Physiomorphic such as pod wall thickness, trichome density and biochemical traits such as mallic acid, oxalic acid, phenols, etc. were identified that contributed to host plant resistance in chickpea crop to H. armigera (Grija et al., 2008). In Pakistan there is lack of research to evaluate the resistance among different host plants against different insect pests. Identification and characterization of insect resistance traits are very important for development and identification of resistant genotypes. As host plant resistance is a vital pillar of Integrated Pest Management (IPM), therefore current study was planned to evaluate the resistance among recent developed genotypes of chickpea.

\section{Materials and Methods}

During cropping season 2018-19, host plant resistance studies were conducted in $C$. arietinum advance lines for $H$. armigera. For this purpose, nine advance lines/ genotypes i.e., K01211, K01216, K01241, K01242, K09012, KO1308, K014001, K014002, K-14003 and check Noor-2013 obtained from Pulses Research Institute, Faisalabad, Pakistan was shown at the research area of Entomological Research Institute, Faisalabad, Pakistan under RCBD design with three repeats and the size of the plot was $15 \mathrm{X} 5 \mathrm{ft}$. A $9 \mathrm{~cm}$ of plant to plant and $1.5 \mathrm{ft}$ of line to line distance were also maintained. Standard agronomic practices were adopted but no plant protection measures were taken during course of study.

For antibiosis and antixenosis studies, $C$. arietinum genotypes/ advance lines were also sown in clay pots having $25 \mathrm{~cm}$ depth and $30 \mathrm{~cm}$ diameter, separately. Five seeds of advance line were dibbed in soil of pots placed in green house. After germination, single plant was maintained in pots and rests were removed by thinning. H. armigera was also reared in the laboratory on artificial diet.

\subsection{Field screening}

Field sown $C$. arietinum genotypes/ advance lines were kept under observation during whole cropping season. Larval population and pod damage percentage was recorded by observing five randomly selected plants per repeat fortnightly. At the end of cropping season, grain yield data were recorded from randomly selected $\mathrm{m}^{2}$ area.

\subsection{Physio-morphic and biochemical traits}

Physio-morphic characters such as Trichome density on chickpea leaves were measured as depicted by Jackai and Oghiakhe (1989) The leaves were cut with scissors and examined under a stereomicroscope (SZM 90) (Made in Japan) at 10X magnification. Pod wall thickness was measured by digital micrometer.

\subsection{Antibiosis}

After 40 days of sowing in pots, when $C$. arietinum plants were at 8-10 branch stage, lab reared newly emerged 10 larvae were released on advance lines separately. Total number of leaves per plant was counted. The pots were later covered with nylon mesh cages with the help of sticks and elastic strip. After 7 days of larval release, advance lines were uncovered and to observe survival rate and development, number of alive and damaged leaves were counted in each repeat.

\subsection{Antixenosis}

Ovipositional non-preference studies were conducted in semi-natural conditions by multi-choice method. Nine $C$. arietinum advance lines, sown in clay pots at square/flower stage, were placed in large nylon mesh cages with dimensions $4 \mathrm{ft} \times 4 \mathrm{ft} \times 6 \mathrm{ft}$. The pots were arranged in cages in a completely randomized design with three replications. Thirty pairs of newly 
emerged male and female $H$. armigera moths with sex ratio of 1:1 were released in each cage. Petri dishes having moist cotton also placed in the cages. After 5 days, number of eggs laid on each advance line were recorded in every repeat.

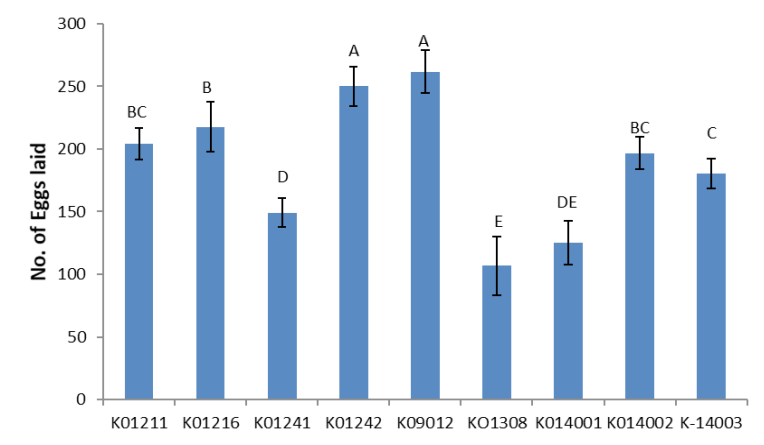

Figure 1: Ovipositional preference of $H$. armigera females on different $C$. arietinum advance lines/ genotypes.

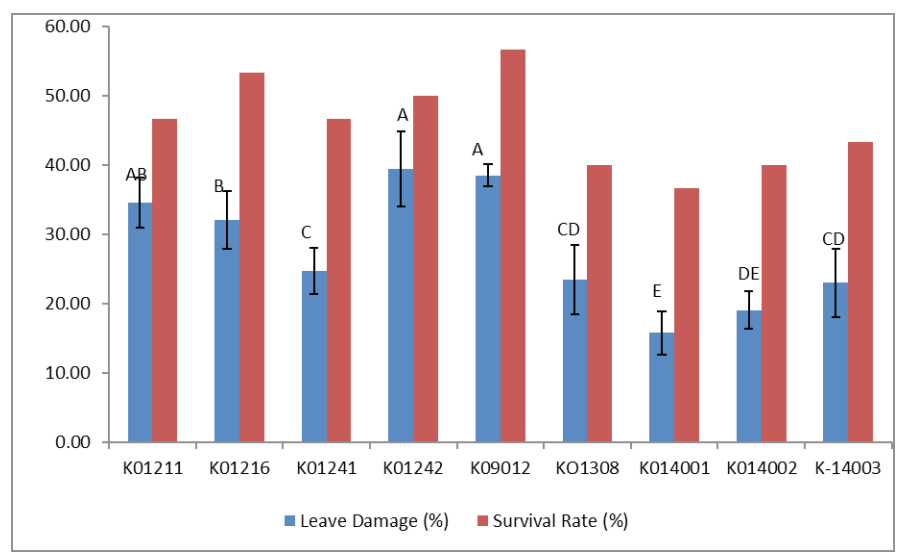

Figure 2: Leaf Damage Percentage of $\boldsymbol{H}$. armigera females on different $C$. arietinum advance lines/ genotype.

\section{Results and Discussion}

\subsection{Field screening}

$H$. armigera population varied significantly among different tested $C$. arietinum genotypes. During the cropping season $H$. armigera larval population ranged from $0.47 /$ plant to $3.40 /$ plant. $H$. armigera infestation firstly recorded during the second fortnight of February that continued to increase till the crop maturity. Similarly, pod borer damage started with the incidence of pest and it ranged from $3.14 \%$ to $26.53 \%$. Genotypes i.e., K01242 and K09012 were observed to be least tolerant where larval density ranged from 1.08 to 3.17/plant and 0.98 to 3.40/plant and damage percentage ranged from $7.25 \%$ to $24.47 \%$ and $6.57 \%$ to $26.53 \%$, respectively.

\subsection{Antixenosis}

Significant differences were observed in the numbers of $H$. armigera eggs laid across different $C$. arietinum genotypes tested by multi choice method in antixenosis experiment. Among the tested genotypes, lowest number of eggs laid by $H$. armigera females were recorded on K01308, that differed non-significantly from number of eggs observed on K014001. Genotypes i.e., K09012 and K01242 were found to be most preferred for oviposition by $H$. armigera females with highest numbers of eggs 261 and 250 , respectively.

\subsection{Antibiosis}

The results revealed that the significant variation in leaf damage percentage was observed among the $C$. arietinum advance lines/ genotypes. Minimum leaf damage percentage about 3.59 was observed in K014001 followed by K014002, K14003 and K01308 showing percentages between 4.8,1.12, 3.14, respectively. Maximum leaf damage percentage 7.57 was recorded in K01242 followed by K09012 (6.57) and K01211. Survival rate of $H$. armigera larva on $C$. arietinum varies non-significantly from one advance lines to other. Maximum larval survival was recorded on K09012 (58.12) followed by K01216. Whereas, minimum was recorded on K014001 (38.2) followed by K01308 and K014002.

One of the vital components of integrated pest management program is the utilization of resistant cultivars against insect pests (Saleem et al., 2021). Ability of insect larvae to feed on host plants efficiently suggests that there exists an inbuilt variation in plant cultivars causing antibiotic effects, antixenosis and antibiosis. These processes may be attributed due to poor nutritional quality of the food, pericarp thickness, and/or secondary plant biochemical (Samraj and david, 1988). Current experiment was performed to evaluate varietal resistance against chickpea pod borer.

The results regarding resistance among the chickpea genotypes against Helicoverpa armigera (Hubner) was evaluated on the basis of larvae per plant, percent pod damage, survival rate and no of eggs laid. It can be inferred from results that chick pea pod borer attacks all the genotypes having no exemption. A range of 0.47 to 3.40 larva/ plant has been recorded in the current experiment on different cultivars however the highest larval density was recorded on K09012 in March which might be because at this interval of time 
Table 1: Field screening of different $C$. arietinum advance lines/genotypes against $H$. armigera.

\begin{tabular}{|c|c|c|c|c|c|c|c|c|c|}
\hline \multirow{3}{*}{$\begin{array}{l}\text { Geno- } \\
\text { types }\end{array}$} & \multirow{2}{*}{\multicolumn{2}{|c|}{$\begin{array}{c}\text { February } \\
2^{\text {nd }} \text { fortnight }\end{array}$}} & \multicolumn{4}{|c|}{ March } & \multirow{2}{*}{\multicolumn{2}{|c|}{$\frac{\text { April }}{1^{\text {st }} \text { fortnight }}$}} & \multirow{3}{*}{$\begin{array}{l}\text { Yield (gm/ } \\
\left.\text { m }^{2}\right)\end{array}$} \\
\hline & & & \multicolumn{2}{|c|}{$1^{\text {st }}$ fortnight } & \multicolumn{2}{|c|}{$2^{\text {nd }}$ fortnight } & & & \\
\hline & $\begin{array}{l}\text { Larval den- } \\
\text { sity /plant }\end{array}$ & $\begin{array}{l}\text { Damage } \\
\text { percentage }\end{array}$ & $\begin{array}{l}\text { Larval den- } \\
\text { sity/plant }\end{array}$ & $\begin{array}{l}\text { Damage } \\
\text { percentage }\end{array}$ & $\begin{array}{l}\text { Larval den- } \\
\text { sity/plant }\end{array}$ & $\begin{array}{l}\text { Damage } \\
\text { percentage }\end{array}$ & $\begin{array}{l}\text { Larval den- } \\
\text { sity/plant }\end{array}$ & $\begin{array}{l}\text { Damage } \\
\text { percentage }\end{array}$ & \\
\hline K01211 & $0.73 \mathrm{BCD}$ & $4.93 \mathrm{ABC}$ & $1.13 \mathrm{BC}$ & $12.11 \mathrm{BCD}$ & $1.80 \mathrm{~B}$ & $15.20 \mathrm{ABC}$ & $2.83 \mathrm{BC}$ & $21.89 \mathrm{ABC}$ & $86.44 \mathrm{BC}$ \\
\hline K01216 & $0.77 \mathrm{BC}$ & $4.49 \mathrm{BC}$ & $1.00 \mathrm{CD}$ & $12.56 \mathrm{ABC}$ & $1.87 \mathrm{~B}$ & $14.81 \mathrm{ABC}$ & $2.67 \mathrm{BCD}$ & $21.38 \mathrm{ABC}$ & $82.08 \mathrm{C}$ \\
\hline K01241 & $0.66 \mathrm{CD}$ & $4.42 \mathrm{BC}$ & $1.13 \mathrm{BC}$ & $10.32 \mathrm{CDE}$ & $1.53 \mathrm{C}$ & $11.86 \mathrm{C}$ & $2.28 \mathrm{DE}$ & $17.59 \mathrm{C}$ & $97.52 \mathrm{ABC}$ \\
\hline K01242 & $1.08 \mathrm{~A}$ & $7.25 \mathrm{~A}$ & $1.23 \mathrm{AB}$ & $13.69 \mathrm{AB}$ & $2.03 \mathrm{~B}$ & $17.20 \mathrm{AB}$ & $3.17 \mathrm{AB}$ & $24.47 \mathrm{AB}$ & $86.39 \mathrm{BC}$ \\
\hline K09012 & $0.98 \mathrm{AB}$ & $6.57 \mathrm{AB}$ & $1.35 \mathrm{~A}$ & $15.71 \mathrm{~A}$ & $2.33 \mathrm{~A}$ & $18.84 \mathrm{~A}$ & $3.40 \mathrm{~A}$ & $26.53 \mathrm{~A}$ & $77.70 \mathrm{C}$ \\
\hline K01308 & $0.47 \mathrm{D}$ & $3.14 \mathrm{C}$ & $0.79 \mathrm{E}$ & $8.01 \mathrm{E}$ & $1.19 \mathrm{D}$ & $12.40 \mathrm{BC}$ & $2.37 \mathrm{CDE}$ & $17.52 \mathrm{C}$ & $103.74 \mathrm{AB}$ \\
\hline K014001 & $0.51 \mathrm{CD}$ & $3.59 \mathrm{C}$ & $0.77 \mathrm{E}$ & $10.32 \mathrm{CDE}$ & $1.53 \mathrm{C}$ & $11.06 \mathrm{C}$ & $1.97 \mathrm{E}$ & $16.56 \mathrm{C}$ & $110.48 \mathrm{~A}$ \\
\hline K014002 & $0.71 \mathrm{BCD}$ & $4.8 \mathrm{BC}$ & $1.00 \mathrm{CD}$ & $9.42 \mathrm{CDE}$ & $1.40 \mathrm{CD}$ & $14.80 \mathrm{ABC}$ & $2.33 \mathrm{CDE}$ & $21.38 \mathrm{ABC}$ & $88.05 \mathrm{BC}$ \\
\hline \multirow[t]{2}{*}{ K-14003 } & $0.76 \mathrm{BCD}$ & $4.76 \mathrm{BC}$ & $0.93 \mathrm{DE}$ & $8.97 \mathrm{DE}$ & $1.33 \mathrm{CD}$ & $12.80 \mathrm{BC}$ & $2.43 \mathrm{CDE}$ & $18.80 \mathrm{BC}$ & $97.94 \mathrm{ABC}$ \\
\hline & 0.1384 & 1.1289 & 0.0866 & 1.4932 & 0.1225 & 2.5066 & 0.2436 & 3.0993 & 9.618 \\
\hline
\end{tabular}

climate becomes feasible for insect development. The current findings are in line with Wakil et al. (2005) who observed a maximum range of 4.05 during march. Varietal comparison proclaimed that K014001 genotype has less number of larvae/plant followed by K014008 comparative to all other cultivars. same trend can also be seen in case of percent damage caused by insect in which both these genotypes have shown $16.56 \mathrm{C}$ and 17.52percentdamage, respectively. These findings strengthen the results of Ali et al. (2012) who reported percent damage up to $20 \%$ on resistant chickpea varieties. Shafique et al. (2009), screened 13 different chickpea genotypes against the borer and noted 13.3 to $22.7 \%$ pod damage as suggested by our study. Similarly, another study conducted by Shafique et al. (2009) also agreed with current findings in his study 10.9 to $22.8 \%$ pod damage was recorded. Similar findings were also observed by Jaba et al. (2017) who reported percent mean pod damage ranged from 68.49 to $100 \%$ in susceptible cultivar.

Yield is another parameter on which basic it can be inferred that certain genotype have shown resistance to certain insect or not. In our present study significant yield difference has been noted among different tested genotypes for resistant studies. Previous results suggest that K014001 is more resistant to Helicoverpa armigera followed by K014008. In case of grain yield K014008 resulted in maximum yield (110.48kg) followed by K014001 yet there is no significant difference between the two in yield parameter. Shafique et al. (2009) also found that least susceptible Kabuli line, $\mathrm{CH} 75 / 02$, has relatively more yield among the thirteen tested strains of chickpea. In case of ovipositional preferences significant difference has been noted among cultivars, however K014008 and K014001 seemed to be less preferred ones for oviposition. Several researcher's including (Rajput et al., 2003; Khan, 2009) evaluated the resistance of chickpea varieties however their experimental areas were located different geographical conditions hence cannot be compared with our findings.

Plant biochemical profile affects the life parameters of host insect. in our current research it was observed that among different tested cultivars of chickpea K09012 provide the highest survival rate to gram pod borer followed by K01216 and minimum was observed on K014001. This shows that K09012 is the most susceptible to $H$. armigera. The difference in survival rate might be related to host plants because every part of the plants (host plant) have its own chemical and physical characteristics that either harbor insect survival on host plant. There are many evidences and reports in research studies showed that the physical and chemical characteristic of the leaves of the plants may affect $H$. armigera survival (Muller and Rosenberger, 2006; Hilker and Meiners, 2006; De Sibioand Rossi, 2012; D'Costa et al., 2013).

\section{Novelty Statement}

Host plant resistance is a vital pillar of Integrated Pest Management (IPM), the results of current study will help the breeder to develop resistant varieties. 


\section{Author's Contribution}

Qurban Ali and Imran Nadeem design supervises the trial, Faheem Akhtar, Asad Aslam and Aqsa Abbas execute the trial, Tamsila Nazir, Asad Aslam and Muhammad Shehzad wrote the research article, Humaira Malik, kanwal Hanif and Hira Iftikhar statistical analyzed the data while Muhammad Jamal and Muhammad Zubair provided helpful material for experiment.

\section{Conflict of interest}

The authors have declared no conflict of interest.

\section{References}

Ali, Q, Elahi M, Ahsan M, Tahir MHN, Khaliq I, Kashif M, Latif A, Ahmed T, Saeed U, Khan NH, Hussain B, Shahbaz M, Shahzadi U and Ejaz M. 2012. Genetic analysis of morphophysiological and quality traits in chickpea genotypes (Cicer arietinum L.). African Journal of Agricultural Research. 7(23), 3403-3412.

Anonymous, 2018. Economic survey of Pakistan, Economic Adviser's Wing, Finance Division Government of Pakistan, Islamabad

Anonymous, 2019. Economic survey of Pakistan, Economic Adviser's Wing, Finance Division Government of Pakistan, Islamabad

Anwar, M., Shafique, M., Ahmad,M., and Shaloori, A.P., 1992. Incidence of attack and population fluctuation of Helicoverpa armigera in relation to chickpea phenology and environmental factors. Proceeding Pakistan Congress of Zoology, 12: 9397.

Bhatt, N.J. and Patel, R.K., 2001. Screening of chickpea cultivars for their resistance to gram pod borer, Helicoverpa armigera. Indian Journal of Entomology, 63(3): 277-280.

D'Costa,L., Koricheva,J., Straw, N., and Simmonds, M.S.J., 2013. Oviposition patterns and larval damage by the invasive horse-chestnut leaf miner Cameraria obridella on different species of Aesculus. Journal of Ecological Entomology, 38: 456-462. https://doi.org/10.1111/een.12037

De Sibio, P.R., and Rossi, M.N., 2012. Oviposition of a leaf-miner on Erythroxylum tortuosum (Erythroxylaceae) leaves: Hierarchical variation of physical leaf traits. Australian Journal of Botany, 60: 136-142. https://doi.org/10.1071/ BT11268
Galdon, B.R., Rodríguez, C.T., Rodriguez, E.M.R. and Romero, C.D., 2009. Fructans and major compounds in onion cultivars (Allium cepa). Journal of Food Composition and Analysis, 22(1): 25-32. https://doi.org/10.1016/j. jfca.2008.07.007

Girija, S.P.M., Patil, S.A., Gowda, C.L.L. and Sharma, H.C., 2008. Biophysical and biochemical basis of plant resistance to pod borer [Helicoverpa armigera (Hubner)] in chickpea (Cicer arietinum L.). Indian Journal of Genetics, 68(3): 320-323.

Hilker, M., and Meiners, T., 2006. Early herbivore alert, insect eggs induce plant defense. Journal of Chemical Ecology, 32: 1379-1396. https://doi. org/10.1007/s10886-006-9057-4

ICRISAT, 2005. Chickpea international crops research institute for the semi-arid tropics. webmastericrisat@cgiar.org

Jaba J, Devrani A, Agnihotri M, Chakravarty (2017) S. Screening of chickpea cultivars against pod borer Helicoverpa armigera (Hubner) under unprotected conditions. Journal of Experimental Zoology, India.20(2):835-43.

Jackai, L.E.N., and Oghiakhe, S., 1989. Pod wall trichomes and role in the resistance of two wild cowpea, Vignavexillata accessions to Marucatestulalis (Geyer), (Lepidoptera: Pyralidae) and Clavigralla tomentosicollois, (Hemiptera: Coreidae). Bulletin of Entomological Research, 79: 595-605. https://doi.org/10.1017/ S0007485300018745

Jukanti, A.K., Gaur, P.M., Gowdal, C.L.L. and Chibbar, R.N., 2012. Nutritional quality and health benefits of chickpea (Cicer arietinum L.): A review. British Journal of Nutrient, 108(1): 11-26. https://doi.org/10.1017/ S0007114512000797

Khan, S.M., 2009. Varietal screening of chickpea and the efficacy of different insecticides against chickpea pod borer Helicoverpa armigera (hb). Gomal University Journal of Research, 25(1): 20-24.

Kranthi, K.R., Jadhav, D.R., Kranthi, S., Wanjari, R.R., Ali, S.S., Russel, D.A., 2002. Insecticide resistance in five major insect pests of cotton in India. Crop Protection, 21: 449-460. https://doi. org/10.1016/S0261-2194(01)00131-4

Kujala, T.S., Loponen, J.M., Klika, K.D., and Pihlaja, K., 2000. Phenolic and Betacyanins in Red Beetroot (Beta vulgaris) root: Distribution 
and effect of cold storage on the content of total phenolic and three individual compounds. Journal of Agriculture and Food Chemistry, 48: 5338-5342. https://doi.org/10.1021/jf000523q

Kulkarni, U.S., Gawande, R.B., Kulkarni, S.S., and Yadgirwar, P.V., 2004. Comparative studies on the biology of Helicoverpa armigera on different food substrates. Journal of Soil Crops, 14: 207208.

Muller, C., and Rosenberger, C., 2006. Different oviposition behavior in Chrysomelid beetles, characterization of the interface between oviposition secretion and the plant surface. Arthropod Structure and Development, 35: 197205. https://doi.org/10.1016/j.asd.2006.06.001

Nimbalkar, R.K., Shinde, S.S., Tawar, D.S., and Muley, S.P., 2009. Response of cotton bollworm Helicoverpa armigera (Hubner) (Lepidoptera: Noctuidae) to different insecticides in Maharashtra, India. World Journal of Agricultural Sciences, 5(2): 250-255.

Rahman, M.M., 1990. Infesting and yield loss in chickpea due to pod borer in Bangladesh. Bangladesh Journal of Agriculture Research, 15(2): 16-23.

Rajput,A.A.,Sarwar,M.,Ahmad,N.,Siddiqui,Q.H., and Toufiq, M., 2003. Evaluation for resistance in some local and exotic chickpea genotypes against Helicoverpa armigera (Hubner). Pakistan Journal of Biological Sciences, 6(18): 1612-1615. https://doi.org/10.3923/pjbs.2003.1612.1615

Saleem, M. J., F Hafeez, Q. Ali, A. Aslam, M. Arshad, D. Hussain, A. Iftikhar, A. Naeem, M. Saleem .2021. Susceptibility of Helicoverpa armigera Hübner (Lepidoptera: Noctuidae) on detached plant parts of transgenic and non-transgenic cotton. International Journal of Tropical Insect Science https://doi.org/10.1007/ s42690-021-00642-0

Samraj, D.A., and David, B.V., 1988. Life table studies on the spotted bollworm, Earias vittella (Fabricious) (Lepidoptera: Noctuidae) in cotton ecosystem. Journal of the Bombay Natural History Society, 85: 637-641.

Sarode, S.V., 1999. Sustainable management of Helicoverpa armigera (Hubner). Pestology, 13(2): 279-284.

Sarwar, M., Ahmad, N. and Toufiq, M., 2009.
Host plant resistance relationships in chickpea (Cicer arietinum L.) against gram pod borer (Helicoverpa armigera Hubner). Pakistan Journal of Botany, 41(6): 3047-3052.

Shafique, M., Nadeem, S., Hamed, M., Atta, B.M., and Shah, T.M., 2009. Performance of some advance desi chickpea genotypes against pod borer, Helicoverpa armigera (Hubner) resistance. Pakistan Journal of Zoology, 41(4): 277-280.

Sharma, H.C., Ahmad, R., Ujagir, R., Yadav, R.P., Singh, R., Ridsdill, S.T.J., 2005. Host plant resistance to cotton bollworm/ legume pod borer, Heliothis/Helicoverpa. In: Sharma HC (ed) Heliothis/ Helicoverpa management: Emerging trends and strategies for future research. Oxford and IBH Publishing, New Delhi, pp. 167-208.

Singletion, V.L., Orthofer, R. and LamuelaRaventos, R.M., 1999. 14 analysis of total phenols and other oxidation substrates and antioxidants by means of folin-ciocalteu reagent. Methods Enzymol., 299: 152-178. https://doi. org/10.1016/S0076-6879(99)99017-1

Suarez, M.H., Rodriguez, E.M.R., and Romero, C.D., 2008. Analysis of organic acid content in cultivars of tomato harvested in Tenerife. European Food Research and Technology, 226: 423-435. https://doi.org/10.1007/s00217-0060553-0

Suzana, C.S., Damiani, R., Fortuna, L.S. and Salvadori, J.R., 2015. Desempenho de larvas de Helicoverpa armigera (Hu"bner) (Lepidoptera: Noctuidae) em diferentes fonts alimentares Pesquisa Agropecu. Trop., 43: 480-485. https:// doi.org/10.1590/1983-40632015v4536733

Wakil, W., Ashfaq, M., and Ahmed, S., 2005. Larval population and pod infestation by Helicoverpa armigera (Hüb.) on chickpea (Cicer arietinum L.) in Rawalpindi, Pakistan. Pakistan Entomologist, 27(1): 33-36.

Zahid, M.A., Islam, M.M., Reza, M.H., Prodhan, M.H.Z., and Rumana, M.B., 2008. Determination of Economic Injury Levels of Helicoverpa armigera (Hubner) in chickpea. Bangladesh Journal of Agriculture Research, 33(3): 555-563. https://doi.org/10.3329/bjar. v33i4.2288 